DOI: http://dx.doi.org/10.37253/jad.v2i2.4967

\title{
Penerapan Ciri Khas Arsitektur Melayu Pada Fasad Bangunan Kontemporer Di Kota Pekanbaru (Kasus Perkantoran Pemerintagan Di Tenayan Raya)
}

\author{
${ }^{1}$ Fadli Rahman, ${ }^{2}$ Harry Kurniawan \\ ${ }^{1}$ Universitas Gadjah Mada, Yogyakarta ${ }^{2}$ Universitas Gadjah Mada, Yogyakarta \\ Email: fadlirahman@mail.ugm.ac.id
}

\section{Informasi Naskah}

Diterima: 26/05/2021; Disetujui terbit: 08/11/2021; Diterbitkan: 31/12/2021; http://iournal.uib.ac.id/index.php/iad

\begin{abstract}
ABSTRAK
Kota Pekanbaru merupakan ibukota Provinsi Riau yang memiliki mayoritas penduduk bersuku Melayu. Dalam menjaga ciri khas kebudayaannya, di kota Pekanbaru banyak terdapat bangunan kontemporer yang memiliki implementasi ciri khas Melayu pada bagian fasad bangunannya, salah satunya pada objek penelitian ini yaitu perkantoran pemerintah di Tenayan Raya. Hal ini dikarenakan ciri khas kebudayaan pada suatu daerah tidak hanya dapat dilihat pada bangunan Rumah Adat Tradisionalnya, tetapi bangunan lainnya juga harus dapat mencerminkan ciri khas daerahnya salah satunya adalah bangunan kantor pemerintahan daerah yang menjadi suatu ciri khas sebuah kawasan. Namun penerapan arsitektur Melayu harus dilakukan sebaik mungkin agar tidak terjadi kesalahan karena dapat mengubah makna yang dikandung dalam setiap ciri khas arsitektur Melayu baik itu pada komponen atap, ornamen ataupun yang lainnya. Kesalah pahaman atau ketidaktahuan seorang perancang dalam membangun juga berdampak fatal terhadap bentukan-bentukan tersebut. Walaupun secara kasat mata bentuk tersebut terkesan indah dirasakan, namun secara filosofi dan makna bisa saja salah. Penelitian ini dilakukan dengan menggunakan metode pendekatan deskriptif untuk menginterpretasikan sebuah kondisi yang ada dengan landasan teori terkait untuk melihat implementasi Arsitektur Melayu pada bagian fasad bangunan kontemporer di Kota Pekanbaru. Seluruh implementasi Melayu pada bangunan di kawasan Perkantoran Tenayan dapat dikategorikan cukup baik dari segi keasliannya karena seluruh atap dan desain ornamennya memiliki motif yang sama dengan motif asli pada bangunan tradisional melayu seperti penerapan jenis atap Lipat Kajang dan pengaplikasian jenis ornamen Hiasan Singgap yang mirip dan sama sekali tidak adanya perbedaan dengan bentuk tradisionalnya. Teknik penerapan ornamen pada objek penelitian ini juga bervariasi, ada yang dilakukan dengan cara Stilasi, Distorsi maupun Repetisi. Namun tidak ditemukannya motif ornamen yang di aplikasikan menggunakan teknik Dekorasi.
\end{abstract}

Kata Kunci: Arsitektur Melayu, Implementasi, Kota Pekanbaru

\section{ABSTRACT}

Pekanbaru City is the capital of Riau Province which has a majority of the population of Malay ethnicity. In maintaining its cultural characteristics, in the city of Pekanbaru there are many contemporary buildings that have the implementation of Malay characteristics on the facades of the buildings, which one is the object of this research, government offices in Tenayan Raya, because the culture in an area is not only can be seen on thel Traditional House building, but other buildings must also be able to reflect regional characteristics such as a regional government office building which is one of the markers of an area. However, the application of Malay architecture must be done as well as possible so that there is no mistake because it can change the meaning contained in each characteristic feature of Malay architecture, meybe on roof components, ornaments or others. Misunderstanding or ignorance of a role in building also has a fatal impact on these formations. 
Although in plain view, these forms seem beautiful to feel, but philosophically and the meaning can be wrong. This research will be conducted with a descriptive approach to interpret an existing condition with a related theoretical basis to see the implementation of Malay architecture on the facades of contemporary buildings in Pekanbaru City. The entire implementation of Malay in buildings in the Tenayan Office area can be categorized as quite good in terms of authenticity because all the roofs and ornamental designs have the same motifs as the original motifs in traditional Malay buildings such as the application of the Lipat Kajang roof type and the application of the Hiasan Singgap Ornament type which is similar and has absolutely no difference with the traditional form. The technique of applying ornament to the object of this research also varies, some are done by means of Stilation, Distortion or Repetition. However, he could not find any ornamental motifs that were applied using Decoration techniques.

Keyword: Malay architecture, implementation, Pekanbaru city

\section{PENDAHULUAN}

Arsitektur Melayu merupakan salah satu langgam Arsitektur Tradisional yang biasanya terdapat pada daerah yang didominasi oleh komunitas Melayu. Arsitektur Melayu merupakan suatu perancangan di bidang arsitektur yang mencerminkan ciri khas suatu nilai adat yang dianut oleh masyarakat suku Melayu.

Provinsi Riau merupakan suatu daerah yang memiliki mayoritas penduduk bersuku Melayu. Sesuai rencananya, ibukota Provinsi Riau yaitu Kota Pekanbaru dalam beberapa tahun kedepan direncanakan akan terus dikembangkan, salah satunya di bidang arsitektur dengan memanfaatkan lahan yang hanya baru digunakan sekitar $30 \%$ dari total luas lahannya. Salah satunya adalah Kecamatan Tenayan Raya yang terpilih dalam pembangunan sebuah kawasan perkantoran yang berfungsi untuk memfasilitasi kegiatan pemerintahan kota Pekanbaru.

Pada kawasan ini akan dibangun beberapa bangunan modern dengan fungsi yang berbedabeda serta bentukan yang beragam dengan mengaplikasikan ciri khas Arsitektur Melayu pada bagian fasadnya seperti menerapkan ornamen khas melayu dan menerapkan beberapa bentukan rumah adat tradisional melayu seperti atap, warna dan lainnya.

Hingga saat ini, di Kota Pekanbaru masih banyak ditemukannya bangunan kontemporer yang didesain dengan menerapkan langgam Arsitektur Melayu. Aplikasi ciri khas arsitektur melayu ini biasanya terbagi menjadi tiga elemen utama, yaitu elemen atap, elemen selembayung dan penggunaan elemen ornamen atau ukiran tradisional melayu.

Pemilihan Perkantoran Pemerintahan Kota Pekanbaru di Kecamatan Tenayan Raya sebagai objek penelitian beralasan karena ciri khas kebudayaan suatu daerah tidak hanya dapat dilihat pada bangunan Rumah Adat Tradisionalnya, tetapi seharusnya juga dapat dilihat dari bangunan lainnya seperti bangunan kantor pemerintahan daerah yang menjadi salah satu marka yang mencerminkan ciri khas daerahnya.

\section{KAJIAN PUSTAKA}

\section{Arsitektur Melayu}

Arsitektur Melayu adalah bagian dari Arsitektur Tradisional Indonesia yang merupakan suatu karya dalam bentuk bangunan maupun lingkungan, yang dimana bentuk, fungsi, ornamen serta cara pembuatannya diwariskan secara turun temurun untuk mewadahi aktifitas manusia sesuai dengan kebutuhannya. Menurut Effendi (2009), bangunan tradisional Melayu merupakan sebuah objek yang digunakan sebagai tempat kediaman keluarga. Selain digunakan sebagai tempat kediaman, bangunan tradisional Melayu biasanya juga digunakan sebagai tempat bermusyawarah, tempat untuk berketurunan serta sebagai tempat untuk berlindung bagi siapapun yang memerlukannya. 
Bangunan tradisional Melayu biasanya dibagi menjadi beberapa bagian elemen, yaitu elemen atap, dinding, ornamen, pintu dan jendela. Arsitektur Melayu di daerah kepulauan Riau memiliki 3 bentukan atap yang berbeda, yaitu atap Lontik, atap Limas, dan atap Belah Bubung/Rebung (Wahyuningsih dan Abu, 1986). Atap Tradisional melayu dapat dibedakan dari jenis bumbungannya, diantaranya yaitu: a) Bumbungan Limas, b) Bumbungan Panjang Sederhana, c) Bumbungan Perak, d) Bumbungan Kombinasi, e) Bumbungan Lima, f) Bumbungan Gajah Minum, dan g) Bumbungan Panjang Berjungkit.

Pada bagian dinding, rumah tradisional Melayu menggunakan 3 teknik penyusunan kayu, yaitu teknik sireh dengan bentuk penyusunan papan secara horizontal, teknik tindih menggunakan bentuk penyusunan papan secara menumpuk seperti susunan bata, sedangkan teknik kaset menggunakan bentuk penyusunan papan secara vertikal (Al Mudra, 2004). Daun jendela pada bangunan Melayu terdiri dari satu hingga dua lembar, sedangkan hiasan pada jendela biasanya disebut Jerajak, hiasan ini digunakan sebagai lambang yang berfungsi sebagai penanda bahwa sang pemilik bangunan merupakan orang yang tahu adat.

Didalam ilmu arsitektur menurut Gustami (dalam Sunaryo 2009: 3), ornamen merupakan sebuah elemen yang berfungsi sebagai hiasan untuk memperindah suatu bagian sisi bangunan. Biasanya komponen ornamen dibuat menggunakan batu, kayu serta logam mulia yang kemudian diukir sesuai keinginan agar menciptakan suatu bentuk yang diinginkan. Ornamen merupakan simbol yang mengandung nilai-nilai simbolik serta makna tertentu yang mewakilkan sebuah kebudayaan. Biasanya, makna yang dikandung dalam sebuah motif ornamen berhubungan dengan falsafah kehidupan serta objek-objek disekitarnya yang dipercayai memiliki makna tersendiri. Ornamen ciri khas Melayu dibedakan menjadi 4 jenis yaitu flora, fauna, agama dan alam. Ornamen tersebut digambarkan dengan bentukan dasar benda yang kemudian sedikit di transformasikan menjadi bentukan tertentu.

Penerapan motif ornamen yang dilakukan pada bangunan kontemporer biasanya dibagi kepada 4 teknik yaitu teknik Stilasi, teknik Distorsi, teknik Repetisi dan teknik Dekorasi. Stilasi merupakan sebuah teknik yang dilakukan dengan cara sedikit mengubah gaya, hal ini dilakukan dengan memberikan sedikit penambahan pada motif dasar yang sudah ada. Untuk Distorsi, merupakan sebuah teknik yang dilakukan dengan cara memberikan perubahan yaitu bentuk yang lebih sedikit disederhanakan. Repetisi merupakan sebuah teknik yang dilakukan dengan cara memberikan pengulangan bentuk motif ornamen baik itu secara vertikal maupun horizontal. Sedangkan Dekorasi yaitu sebuah teknik yang dilakukan dengan cara memberikan sedikit penambahan bentuk dengan tujuan menghasilkan bentukan baru yang lebih indah.

\section{Fasad Arsitektur}

Fasad merupakan bahasa Perancis yang berasal dari bahasa Italia yaitu facciata. Facciata berasal dari bahasa Latin yaitu facies. Sesuai dengan artinya, didalam dunia arsitektur fasad dapat diartikan sebagai wajah bangunan, kulit bangunan atau bagian terluar pada bangunan. Fasad merupakan sebuah elemen yang sangat penting didalam dunia arsitektur karena merupakan bagian yang pertama kali dilihat oleh penikmat karya arsitektur. Maka oleh sebab itu, fasad merupakan suatu unsur yang tidak bisa dikesampingkan dari sebuah desain produk arsitektur. (Sastra, 2013:3-5)

Fasad merupakan elemen estetis pada suatu bangunan karena fasad merupakan elemen pertama yang dilihat secara visual serta berfungsi sebagai point of interest yang menerjemahkan karya arsitektur. Menurut Ramadanta, komposisi bagian fasad bangunan dapat dilihat pada bagian fungsionalnya seperti pada atap, jendela, pintu, dan sun shading dalam menciptakan sebuah kesatuan yang harmonis, pada prinsipnya dapat dilakukan dengan 
menggunakan komposisi dan proposi, seperti penggunaan material, warna, dan elemenelemen dekoratif yang digunakan secara terstruktur.

Menurut Ching (1985) dalam Fikroh, dkk (2016), fasad pada bangunan terbagi menjadi 3 bagian, diantaranya adalah komponen fasad bangunan, komposisi fasad bangunan dan unsur fasad bangunan.

\section{Nilai Estetika Dalam Fasad}

Menurut Arenibafo (2017), estetika pada objek arsitektur merupakan sebuah gaya desain tertentu yang bertujuan membuat suatu objek agar terlihat menarik dan indah untuk dilihat, hal ini dapat dilihat pada estetika bagian eksterior yang didasari oleh rasa dan penilaian indera manusia.

Diperlukannya proporsi yang sesuai dengan standar nilai estetika dalam menerapkan elemen-elemen pembentuk fasad agar dapat terbentuknya suatu kesatuan yang baik. Menurut Teori Santayana dalam Wahba (2010), terdapat beberapa faktor yang digunakan pada komposisi arsitektur agar mendapatkan nilai estetika, faktor tersebut adalah bentuk, dimensi, irama, tingkat kerumitan dan keberaturan.

\section{METODE PENELITIAN}

Lokasi objek yang pertama (Perkantoran Pemerintah Kota Pekanbaru), terletak pada Komplek Perkantoran Pemerintah Kota Pekanbaru, Kelurahan Sail, Kecamatan Tenayan Raya, Kota Pekanbaru, Provinsi Riau.

Penelitian ini dilakukan dengan menggunakan pendekatan deskriptif yaitu dengan menginterpretasikan suatu kondisi yang ada dan didasari oleh landasan teori terkait untuk melihat sebuah implementasi Arsitektur Melayu pada bagian fasad bangunan kontemporer di Kota Pekanbaru. Penelitian ini dilakukan dengan menggunakan teknik pengumpulan data primer dan data sekunder.

\section{HASIL DAN PEMBAHASAN}

\section{Analisis Arsitektur Melayu Pada Fasad}

\section{A. Perkantoran Pemerintah Kota Pekanbaru di Tenayan Raya}

Bangunan perkantoran Pemerintah Kota Pekanbaru di Tenayan Raya merupakan sebuah bangunan baru yang didirikan sebagai wadah untuk memenuhi kegiatan administrasi Kota Pekanbaru, bangunan ini mulai beroperasi sejak tahun 2018. Pada kawasan ini terdapat 7 bangunan dengan fungsi yang berbeda antara setiap bangunannya, dimana setiap bangunan menampung dua sampai tiga fungsi utama untuk memenuhi kegiatan administrasi kota. Seluruh bangunan pada kawasan ini memiliki kombinasi warna yang sama yaitu cokelat tua, cokelat muda, oranye serta biru dengan bentukan desain yang relatif sama, perbedaan hanya dapat terlihat pada bagian atapnya, kecuali pada bangunan utama dengan bentuk desain yang berbeda dengan bangunan lainnya.

\section{Bangunan Utama}

Bangunan utama terdiri dari 7 tingkat termasuk basement, bangunan ini terletak pada bagian depan kawasan sehingga dapat menyambut pengunjung dengan memberikan kesan megah dengan karakter melayu yang dimilikinya. Jika dilihat dari jauh, bangunan utama tidak sedikitpun terlihat ciri khas kemelayuannya, namun jika diamati dari dekat maka ciri khas melayunya akan terlihat jelas terutama pada setiap jendelanya karena terdapat banyak sun-shading yang berfungsi untuk meminimalisir cahaya matahari yang masuk ke dalam 
bangunan melalui jendela dengan menggunakan motif ornamen khas melayu. Terdapat beragam jenis ornamen khas melayu yang diimplementasikan pada bangunan ini dengan bentukan yang beragam pada setiap jendelanya namun terdapat beberapa motif ornamen yang sama. Bangunan utama ini menggunakan warna dasar cokelat muda yang dikombinasikan dengan warna cokelat tua, putih, kuning, oranye dan biru. Atap pada bangunan utama memiliki desain berbentuk kubah, hal ini menyimbolkan bahwa Islam sebagai identitas Melayu serta melambangkan hubungan erat antara adat dan keimanan karena Islam merupakan dasar utama dalam terbentuknya kebudayaan melayu. Selain itu corak dan pemikiran Melayu juga dipengaruhi oleh ajaran islam seperti kebudayaan dalam menjalankan kehidupan dan motif-motif yang diambil untuk diterapkan pada bangunan melayu seperti motif kaligrafi yang dikutip dari ayat-ayat suci Al-Quran dan pemakaian bentuk kubah sebagai atap bangunan.

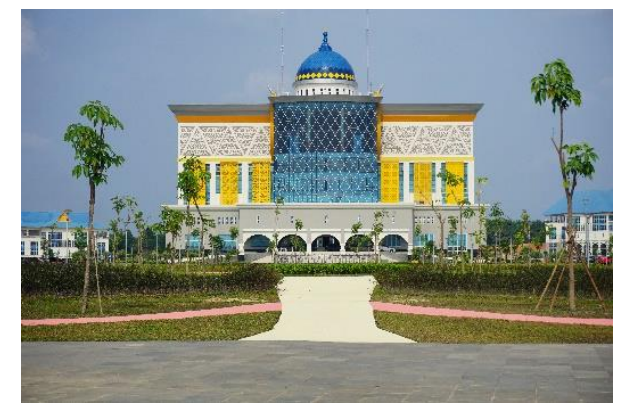

Gambar 1. Bangunan Utama Perkantoran Tenayan Raya

Sumber: Pribadi, 2021

Selain berfungsi sebagai elemen penunjang estetika, ornamen pada bangunan ini juga berfungsi sebagai fasad sekaligus shading bagi bangunan guna mengurangi intensitas cahaya yang masuk ke bangunan sehingga panas yang ditangkap oleh bangunan dapat dikurangi dengan cukup signifikan. Selain itu ornamen ini juga berfungsi sebagai elemen penunjang estetika guna memperindah tampilan fisik bangunan. Beberapa jenis ornament yang dominan digunakan oleh bangunan utama Perkantoran Tenayan Raya diantaranya; Ornamen Payung Sekaki, Ornamen Tentedu Bergelut Daun, Ornamen Pucuk Rebung, Ornamen Kuntum Bujang, Ornamen Pucuk Bersusun, Ornamen Kuntum Bersanding, Ornamen Pucuk Rebung, Ornamen Awan Larat, Ornamen Itik Sekawan, Ornamen Ayam Berjurai Peno-Peno, Ornamen Gerak Gempa, Ornamen Tampuk Manggis, Ornamen Hiasan Singgap, Ornamen bunga Kiambang dan Ornamen Kelopak daun

\section{Bangunan Penunjang}

Penerapan ciri khas bangunan melayu pada bangunan penunjang yang terdapat disekitar bangunan utama ini dapat dilihat dari bentukan bangunan berbeda-beda yang merepresentasikan rumah adat dari berbagai kabupaten yang terdapat di Provinsi Riau. Bangunan penunjang ini menggunakan beberapa bentukan atap yang berbeda-beda, diantaranya:

a. Bumbungan Limas: atap Limas Penuh

Bentukan atap pada bangunan ini menggunakan atap limasan dengan penambahan selasar pada bagian depan. Bentukan atap ini biasanya digunakan sebagai atap pada bangunan istana, kediaman bangsawan dan juga sebagai balai pertemuan. Selain bentukan limasan yang terdapat pada bangunan, jumlah tangga dan tiang kurang merepresentasikan bangunan melayu pada bangunan ini yang seharusnya memiliki jumlah genap. 
b. Bumbungan Panjang Berjungkit: atap Lontik

Bentukan atap yang terdapat pada bangunan ni disebut lontik dikarenakan bentukan pada tulang bumbungannya yang meruncing keatas atau lentik yang disebut dalam Bahasa melayu sebagai Lontik. Bangunan ini biasa berfungsi sebagai tempat pertemuan, tempat tinggal, rumah penyimpanan dan lain sebagainya. Atap bangunan berbentuk Lontik ini juga cukup sulit ditemui terkecuali pada beberapa daerah seperti Pasir Pengaraian, Kampar dan Indragiri Hulu.

c. Bumbungan Sederhana: atap Lipat Kajang

Atap pada bangunan ini berbentuk agak melandai dengan selasar pada bagian depan bangunan. Atap ini merupakan lambang dari sifat yang lurus, adil, benar dan menjunjung tinggi rasa gotong royong dan musyawarah. Beberapa ornament juga terletak pada bagian bawah atap yang dikenal dengan Hiasan Singap. Ornament ini memiliki makna sebagai symbol beradat dan berlembaga.

d. Bumbungan Sederhana: atap Lipat Kajang

Pada bangunan ini, strukturatap yang dimiliki adalah struktutr atap lipat kajang. Atap ini memuliki bentuk selasar pada bagian depan yang berbeda dari bangunan sebelumnya. Atap ini juga merupakan lambang dari sifat yang lurus, adil, benar dan menjunjung tinggi rasa gotong royong dan musyawarah. Beberapa ornament juga sama dengan bangunan sebelumnya yaitu Hiasan Singap. Ornament ini memiliki makna sebagai symbol beradat dan berlembaga.

e. Bumbungan Sederhana: atap Limas Potong

Pada bangunan ini struktur atapnya berbentuk limas terpotong pada bagian tengah keatas. Atap ini juga merupakan lambang dari sifat yang lurus, adil, benar dan menjunjung tinggi rasa gotong royong dan musyawarah. Selain itu juga terdapat ornamen yang dikenal dengan Hiasan Singap yang terletak pada bagian bawah atap. Ornament ini memiliki makna sebagai simbol beradat dan berlembaga.

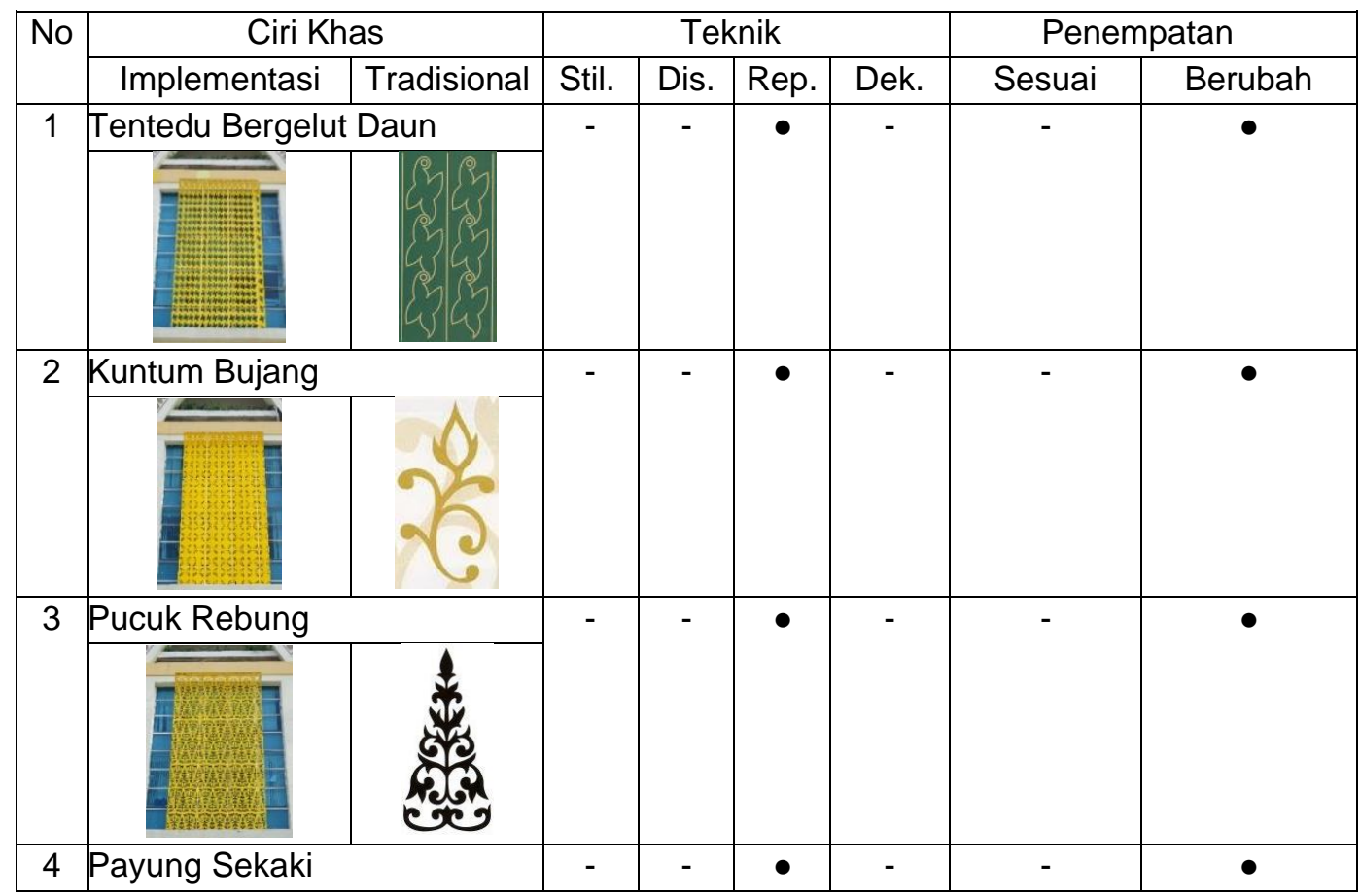




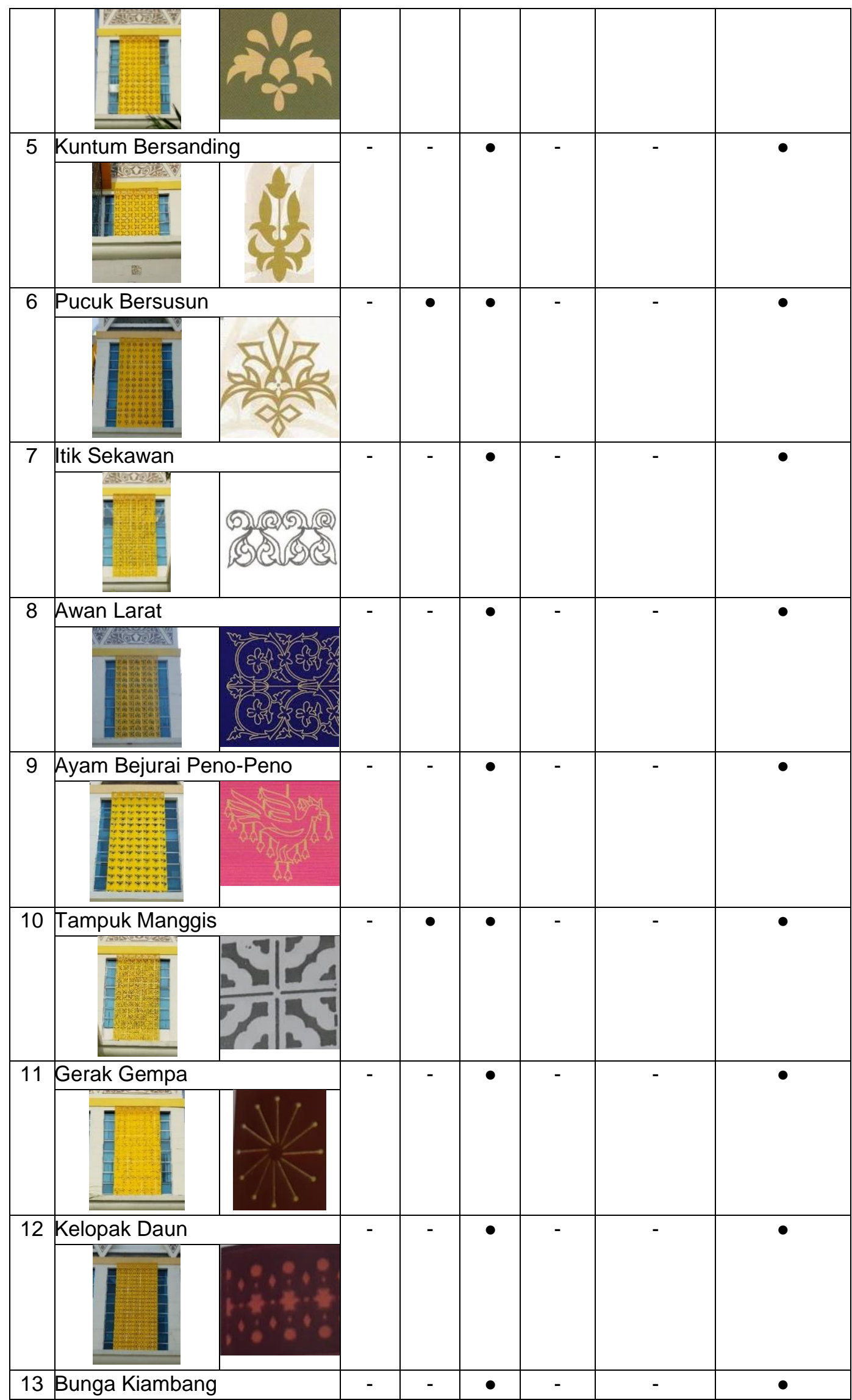

109 ل\D-Vol.02/No.02, Desember 2021 


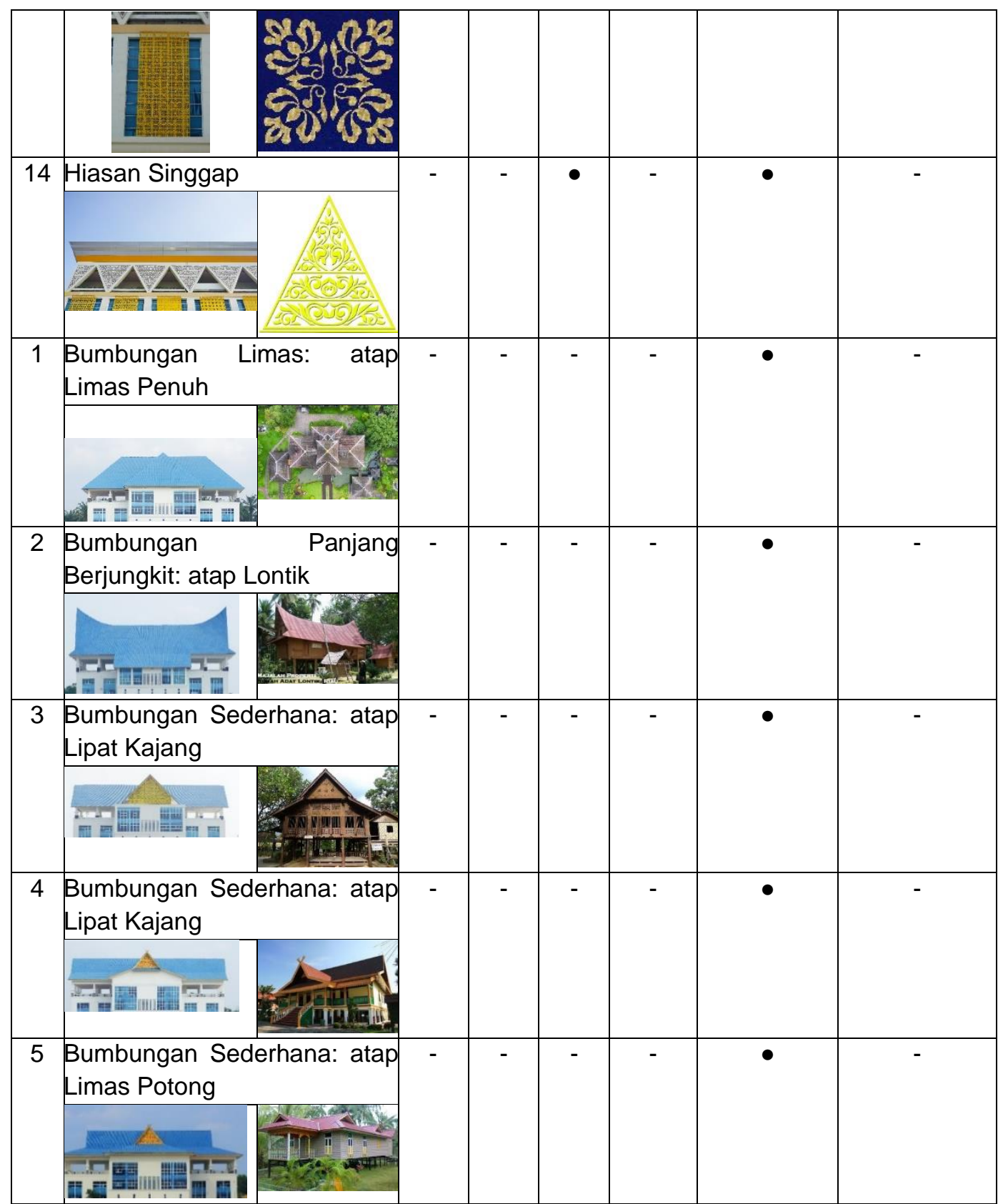

Tabel 1. Analisis Arsitektur Melayu pada fasad

\section{Analisis Nilai Estetika Arsitektur Pada Fasad}

1. Bentuk

Bangunan yang terdapat pada lokasi penelitian ini memiliki bentuk dasar persegi panjang dengan atap berbentuk segitiga. Namun hal yang berbeda ditunjukan oleh bangunan utama yang memiliki bentuk atap yang melingkar seperti kubah. Jika diperhatikan dari bagian fasad, hamper seluruh bangunan memiliki bentuk serupa, yaitu dengan bentuk persegi empat yang melebar dan menjorok kedepan pada bagian tengahnya. Pola ini juga sama dengan bentuk seluruh jendela, ventilasi dan juga pintu.

Jika diperhatikan dengan bentukan 3 dimensi, bangunan ini memiliki elemen yang serupa dan tersusun berirama yang berbentuk persegi Panjang sebagai bentuk utamanya. Hal ini dapat diperhatikan dari penyusunan jendela dan ventilasi yang terkesan rapi dan harmonis. 


\section{Dimensi}

Dimensi dan proporsi pada objek perancangan juga memenuhi prinsip proporsi. Hal ini dapat dilihat dari komposisi bangunan utama dan bangunan penunjang disekitarnya. Bangunan utama memiliki bentuk yang lebih besar dan lebih mendominasi dibanding bangunan sekitarnya serta bangunan utama juga terletak pada bagian depan tengah dari kawasan perancangan ini sehingga bangunan utama juga dapat berfungsi sebagai entrance untuk memasuki Kawasan ini. Selain itu, bentukan masing-masing bangunan juga memiliki entrance yang menjorok kedepan yang lebih kecil dari objek dibelakangnya.

Prinsip proporsi juga terpenuhi akibat kombinasi desain atap dan desain dinding. Seluruh desain atap pada objek penelitian ini memiliki ukuran atap yang sedikit lebih kecil dari pada ukuran dindingnya dengan perkiraan perbandingan 2:3. Namun jika diamati dalam perspektif 3 dimensi, objek penelitian ini memiliki perbandingan 2:1 antara panjang dinding bagian depan dengan panjang dinding bagian sampingnya.

Fasad bangunan ini memiliki desain yang melebar namun tetap memiliki tinggi yang sesuai sehingga tetap mempunyai kesan megah terhadap bangunan. Hal ini dikarenakan desain atap yang menjulang tinggi dan penambahan ruang tanpa dinding pada bagian bawah atapnya yang memberikan tampilan seperti rumah panggung yang berfungsi untuk meminimalisir panas dari cahaya matahari.

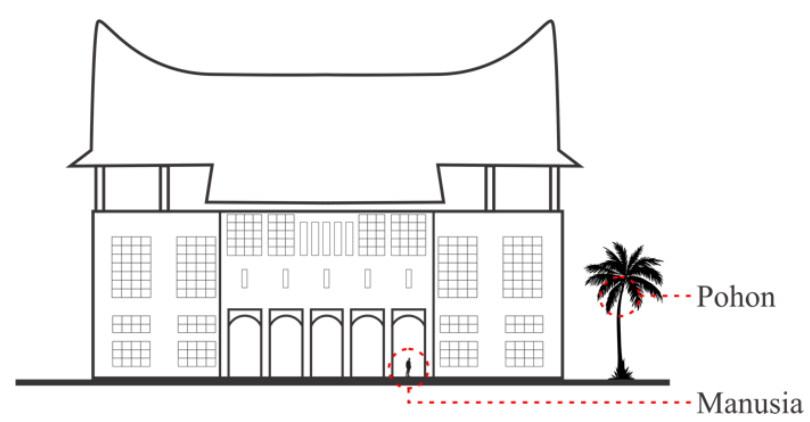

Gambar 2. Analisis Ilustrasi Dimensi Perkantoran Tanayan Raya Sumber: Pribadi, 2021

\section{Irama}

Pengulangan pada objek perancangan ini dapat dilihat dari bentukan dasar bangunan yang memanjang. Hal ini diterapkan berulang pada bangunan penunjang disekitar bangunan utama. Pengulangan juga terdapat pada beberapa elemen bangunan lainnya, diantaranya: ventilasi, ornament, kolom dan jendela yang memiliki jarak serta bentuk yang simetris antara satu dengan yang lain. Selain itu beberapa elemen pendukung yang cukup kontras di aplikasikan pada beberapa bagian seperti kolom pada bagian depan bangunan dan atap bangunan utama yang berbentuk kubah dan lingkaran yang juga diletakkan secara simetris dan seimbang antara bagian kiri dan kanan.

\section{Tingkat Kerumitan}

Tingkat KerumitanTingkat kerumitan pada bangunan ini dinilai cukup sederhana. Penggunaan material yang cukup mudah didapat. Material pada bangunan ini didominasi oleh beton sebagai material utama, kaca, seng dan ACP sebagai material lainnya.

\section{Keteraturan dan Ketidak Teraturan}

Elemen-elemen pembentuk pada bangunan ini diletakkan dengan cukup teratur. Hal ini dapat dilihat dari perletakan Double Skin yang berbentuk ukiran melayu yang terletak secara simetris, teratur dan sangat berirama. Perletakan kolom, ventilasi, jendela dan perabung juga 
dinilai sangat teratur dan simetris antar bagian bangunan. Sedangkan pada bangunan penunjang lainnya, keberadaaan ornament justru dinilai cukup minim. Pada bangunan pendukung ini tidak terdapat banyak ornament, namun perletakan jendela dan ventilasi dinilai juga cukup teratur dan simetris.

\section{Kesimpulan}

Implementasi melayu pada keseluruhan bangunan di Kawasan Perkantoran Tenayan ini dikategorikan cukup baik. Hal ini dinilai dari keorisinalitasan desain ornament dan juga motif melayu yang serupa dengan bentukan asli pada ornament dan motif tradisionalnya. Walaupun terdapat beberapa ornament yang dimodifikasi oleh perancang, motif dan ornament ini masih dapat dikenali dengan mudah oleh para pengamat. Objek perancangan ini jugamemiliki warna dasar kuning, keemasan, hijau dan cokelat juga dinilai sesuai dengan kaidah-kaidah yang terdapat dalam kebudayaan melayu.

Penerapan ornamen-ornamen pada bangunan ini juga memiliki teknik yang bervariasi. Diantaranya dengan cara distilasi, distorsi dan juga repetisi. Namun teknik pemasangan ornament dengan cara dekorasi tidak dapat ditemukan pada komplek bangunan ini. Ornament dan motif yang dipilih untuk diimplementasikan pada bangunan ini juga sering ditemui dan dilihat baik pada rumah tradisional maupun kain tenun khas melayu sehingga dapat dengan mudah dikenali oleh para pengamat. Namun beberapa ornament diimplementasikan ditempat yang kurang tepat menurut kaidah ornament melayu. Hal ini tentunya mengakibatkan perubahan makna dikarenakan penempatannya yang kurang tepat.

Kesalahan dalam menginterpretasikan arsitektur Melayu ini sering terjadi dikarenakan kurangnya control dari pemerintah, budayawan dan juga asosiasi arsitek setempat. Hal ini tentu mengakibatkan perubahan makna dan filosofi yang terdapat pada bangunan ini sehingga hal ini dapat berpengaruh terhadap arsitektur suatu bangunan yang merupakan wajah dari suatu kota ataupun daerah. Ketidak tahuan dan kesalah fahaman perancang juga berdapat terhadap bentukan-bentukan yornamen yang diterapkan pada bangunan. Walaupun dirasa memiliki nilai estetika yang cukup bagus namun jika dinilai secara filosofis dan makna dari objek tersebut dapat terjadi pergeseran. Hal ini harusnya dapat diminimalisir dengan aturan, kebijakan dan pengawasan oleh pemegang kekuasaan dan juga sosialisasi terkait penggunaan ciri arsitektur local pada suatu daerah.

Implementasi ciri arsitektur melayu pada bangunan kontemporer hanya bersifat pernakpernik. Hal ini dikarenakan tidak ada arsitektur Melayu yang modern, melainkan arsitektur modern yang memiliki nuansa Melayu. Arsitektur melayu memiliki pola berpikir (metode Perancangan), analisa, material yang bersifat turunan dari pendahulu yang memiliki unsur mistis dalam proses perletakan dan pengaturan posisi sebuah ornamen pada suatu bangunan. Oleh sebab itu, peimplementasian ornament melayu pada fasad suatu bangunan dapat dikatakan sebagai bangunan modern dengan nuansa melayu.

Secara estetika, Perkantoran Tenayan Raya ini juga memiliki tingkat estetika yang cukup baik. Bentuk irama, dimensi, keberaturan dan juga tingkat kerumitan pada bangunan ini menghasilkan kombinasi yang cukup rapi dan teratur serta megah yang membuat bangunan ini cukup nyaman dipandang.

\section{Daftar Pustaka}

Arfianto, D. R. (2007). Pekanbaru Trade Centre" Transformasi Bangunan dengan Karakteristik Arsitektur Melayu Riau". 
Aurelia, N., Winandari, M. I. R., \& Iskandar, J. (2019). Tipologi Fasad Arsitektur Tradisional Melayu Riau. Mintakat: Jurnal Arsitektur, 20(1), 1-8.

Faisal, G., \& Wihardyanto, D. (2013). Selembayung Sebagai Identitas Kota Pekanbaru: Kajian Langgam Arsitektur Melayu. Indonesian Journal of Conservation, 2(1).

Hidayat, W. (2011). Aplikasi Langgam Arsitektur Melayu Sebagai Identitas Kawasan Menuju Kota Berkelanjutan. Local Wisdom: Jurnal IImiah Kajian Kearifan Lokal, 3(2), 27-32.

Molindhuri, S. (2010). Pusat budaya melayu Riau di Pekanbaru dengan penekanan pada pemanfaatan karakter arsitektur tradisional melayu Riau sebagai ekspresi bangunan.

Prayoga, E. G., \& Anisa, A. (2019). Pendekatan Arsitektur Tradisional Pada Bangunan Pendidikan Berkonsep Modern "Karol Wojtyla" Universitas Katolik Atma Jaya. Purwarupa Jurnal Arsitektur, 3(3), 193-198.

Primasari, D. A., Amanati, R., \& Rijal, M. (2015). Sentra Kerajinan Tenun di Pekanbaru dengan Pendekatan Tampilan Visual Arsitektur Melayu (Doctoral dissertation, Riau University).

Putra, IDGAD. (2017) Konsepsi Dan Makna Arsitektur Tradisional Pada Bangunan Kekinian. Jurnal Universitas Mercu Buana

Ramadanta, A. (2010). Kajian Tipologi dalam Pembentukan Karakter Visual dan Struktur. Jurnal SMARTek, Vol.8 No.2.

SILITONGA, N. N. (2020). Penerapan Arsitektur Tradisional Toraja Pada Bangunan Gereja Tongkonan Kelapa Gading, Jakarta (Doctoral dissertation, Universitas Mercu Buana Jakarta).

Silva, H. (2015). Identifikasi Arsitektur Melayu Di Kota Pekanbaru. Jurnal Arsitektur Melayu dan Lingkungan, 2(1), 73951.

Susanta, I. N., \& Wiryawan, I. W. (2016, April). Konsep Dan Makna Arsitektur Tradisional Bali Dan Aplikasinya Dalam Arsitektur Bali. In Workshop 'Arsitektur Etnik Dan Aplikasinya Dalam Arsitektur Kekinian (Vol. 19, p. 1).

Wahyudi, M. A. (2016). Karakteristik Rumah Tradisional Di Pesisir Kilen Jawa Tengah Studi Kasus Rumah Tradisional di Desa Krajan Kulon, Kaliwungu, Kendal. Teknis, 10(3).

Wahyuningsih; Abu, Rivai.Arsitektur Tradisional Daerah Riau .1986/1987

Wibowo, M., \& Aprimavista, P. A. (2015). Terapan Konsep Bangunan Tradisional Bali pada Objek Rancang-Bangung Karya Popo Danes (Doctoral dissertation, Petra Christian University) 